\title{
Autocephaly in the Light of the Preparations to the Pan-Orthodox Council
}

\author{
Archimandrite Andrzej Borkowski \\ Katedra Teologii Prawosławnej \\ Uniwersytet w Białymstoku \\ Polska \\ borkowskiunath@yahoo.gr
}

\begin{abstract}
Archimandryta Andrzej Borkowski, Autokefalia w świetle przygotowań do Wielkiego Soboru, Elpis, 18 2016: 165-170.
Abstract: Among the topics submitted, but finally not elaborated and discussed at the Pan-Orthodox Synod, is found the manner of granting autocephaly. Calling the Great Synod signifies a revival of the institution of conciliarity's activity at the Pan-Orthodox level in a similar manner as at the Great Ecumenical Councils. Unfortunately, the issue of autocephaly was not approved at the Fifth Pre-Conciliar Pan-Orthodox Conference. The topic of autocephaly and the means by which it is proclaimed did not receive the required unanimous voting (consensus) despite the in-depth discussion at the Inter-Orthodox Preparatory Commission and the Pre-Conciliar Pan-Orthodox Conference meetings. The resolutions of the abovementioned meetings and lively discussion provoked by the topic, gave the question of autocephaly a new dimension and produced new elements and theories. The manner of granting autocephalous status in the Orthodox Church is an extremely important question today and is awaiting a solution by establishing commonly accepted canons which guarantee the preservation of Orthodox unity. The difficulties experienced in the discussion are caused a the lack of specific and clear canonical resolutions regarding the meaning of autocephaly, the conditions of granting it, who is the responsible organ for its granting or deprivation, and also concerning the internal relations of daughter Churches with their Mother Churches and their relations with the remaining Autocephalous Churches.
\end{abstract}

\begin{abstract}
Streszczenie: Wśród przedłożonej tematyki, która nie została ostatecznie wypracowana i przedłożona na Soborze panprawosławnym znajduje się sposób ogłaszania autokefalii. Zwołanie Wielkiego Soboru oznaczało wznowienie działalności instytucji soborowości na szczeblu ogólnoprawosławnym, na wzór Soborów powszechnych. Niestety, podczas V Komisji przygotowawczej, na której poruszono temat autokefalii nie osiągnięto ostatecznej zgody. Temat sposobu ogłaszania autokefalii kościelnej, pomimo dogłębnej dyskusji w ramach Międzyprawosławnej Komisji Przygotowawczej i Ogólnoprawosławnej Konferencji Przedsoborowej, nie uzyskał wymaganej jednogłośnej zgody - konsensusu. Uchwały powyższych spotkań oraz wywołana w ich wyniku żywa dyskusja, dodały kwestii autokefalii nowy wymiar oraz wniosły nowe elementy i teorie. Sposób udzielania ustroju autokefalii w Kościele prawosławnym stanowi dziś niezwykle ważną kwestię, oczekującą na rozwiązanie przez ustalenie wspólnie przyjętych kanonów, będących gwarantem zachowania jedności Prawosławia. Trudności w dyskusji polegają na braku konkretnych i jasnych uchwał kanonicznych odnośnie znaczenia pojęcia autokefalii, warunków jej udzielania, kto jest odpowiedzialnym organem udzielania lub jej pozbawiania, ale także odnośnie wewnętrznych relacji Kościoła-córki i Kościoła-matki oraz tych z pozostałymi Kościołami autokefalicznymi.
\end{abstract}

Keywords: Orthodox Church, autocephaly, Pan-Orthodox Synod

Słowa kluczowe: Kościół prawosławny, autokefalia, sobór pan-prawosławny

The institution of autocephaly originates in the Pentarchy of the ancient patriarchates. However, in recent years, the system of autocephaly has been experienced through the "spirit" of ethnofiletism, thus creating the impression that it is a federation of national churches. Among the topics submitted, but finally not elaborated and discussed at the Pan-Orthodox Synod, is found establishing an order for mentioning local churches in the diptychs and the manner of granting autocephaly. ${ }^{1}$ Calling the Great Synod sig-

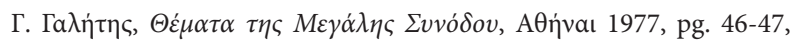

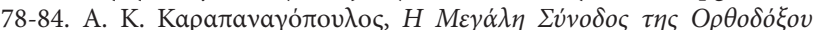

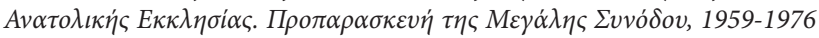

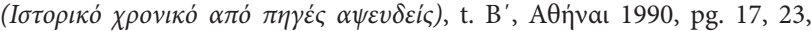

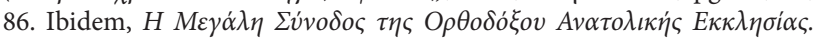

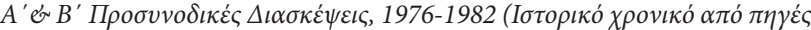

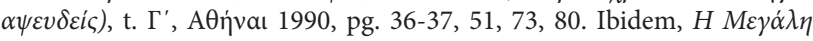

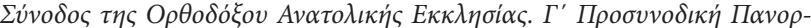

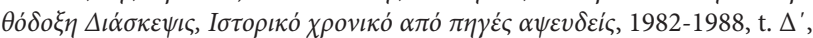

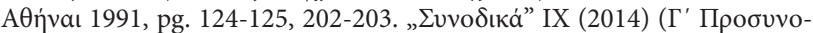

nifies a revival of the institution of conciliarity's activity at the Pan-Orthodox level in a similar manner as at the Great Ecumenical Councils. ${ }^{2}$ Unfortunately, the issue of diptychs

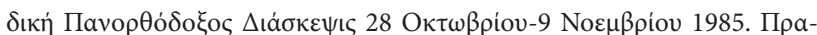

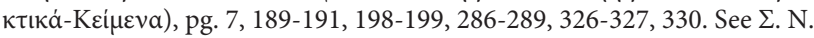

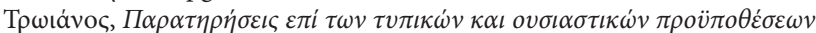

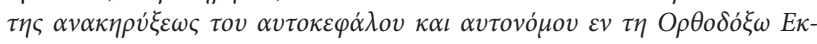

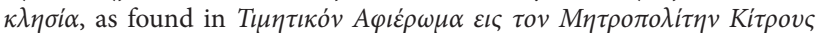

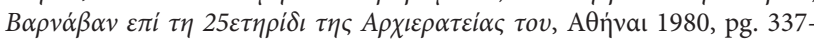

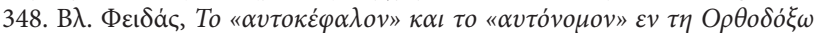

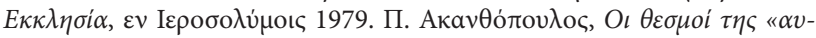

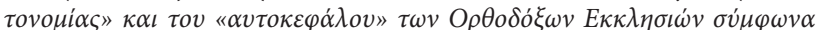

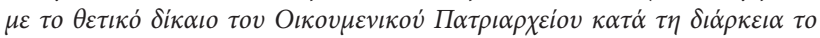

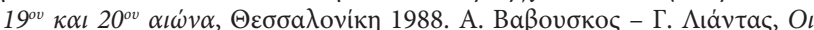

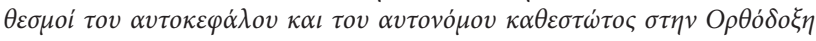

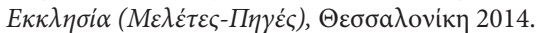

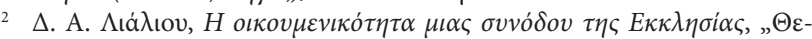
oגoyía" 86/4 (2015), pg. 31-36. Biskup Jerzy (Pańkowski), Czym jest sobór (Sobór Wszechprawosławny) dla Kościoła? Perpektywa prawosławna, „Polski Żołnierz Prawosławny” rok XXIII, nr 2/88 (2016), pg. 3-7. 
and autocephaly was not approved at the Fifth Pre-Conciliar Pan-Orthodox Conference. The topic of autocephaly and the means by which it is proclaimed did not receive the required unanimous voting (consensus) despite the indepth discussion at the Inter-Orthodox Preparatory Commission and the Pre-Conciliar Pan-Orthodox Conference meetings. The resolutions of the abovementioned meetings and lively discussion provoked by the topic, gave the question of autocephaly a new dimension and produced new elements and theories, which I will attempt to mention. However, I believe that it is necessary to mention the factors that influenced the commencement of the procedure and brought to mind the necessity of calling the Great and Holy Synod of the Orthodox Church.

Beginning in 1902, Ecumenical Patriarch Joachim III spoke of the need to call a meeting of the Orthodox Churches in order to strengthen mutual co-operation. ${ }^{3}$ Two years later, the Patriarch explained that significant differences and problems should be analyzed by representatives of particular Orthodox Churches with the aim of strengthening the consciousness of unity. The Ecumenical Patriarch undertook the abovementioned initiative bearing in mind the regulation of inter-Orthodox relations, which are needed for a joint resistance against ethnofiletism. In 1920, The Ecumenical Patriarch called not only Orthodox Churches to mutual assistance and co-operation. ${ }^{4}$ The next significant step was calling the Pan-Orthodox Conference in Constantinople in May, 1923 by Patriarch Meletius IV Metaxakis and a subsequent Conference in the Vatoped Monastery on Mount Athos on 8-23 June, 1930 by Patriarch Photius II. The list of topics elaborated for the future pro-Synod also contained the question of establishing the number of Autocephalous Churches and the conditions and means of granting autonomy, autocephaly and Patriarchal dignity. The meeting took place in the shadow of the Balkan wars and Megali Idea. Later, the outbreak of the Second World War did not permit the continuation of the already initiated pre-Council process ${ }^{5}$.

The next step towards the Great Council was the First Pan-Orthodox Conference, which took place in Rhodes between September $24^{\text {th }}$ and October $1^{\text {st }}, 1961$. Its main objective was to formulate a final list of topics, which would

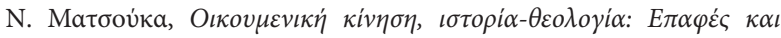

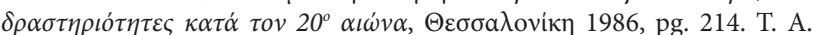
Meimaris, The Holy and Great Council of the Orthodox Church \& the

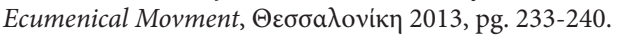

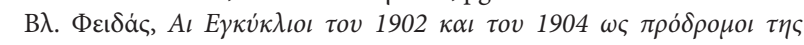

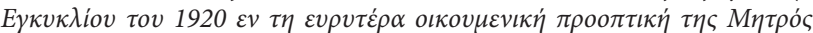

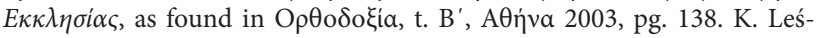
niewski, Jedność chrześcijan $w$ oficjalnych wypowiedziach Kościoła prawosławnego, „Sympozjum” 4 (2000), nr. 1, pg. 23-24. T. Kałużny, Nowy Sobór Ogólnoprawosławny. Natura, historia przygotowań, tematyka, Kraków 2008, pg. 139-143.

5 J. Tofiluk, O przygotowaniach do Soboru Wszechprawosławnego, „Elpis” 1 (1999), nr 1, pg. 69-71. T. Kałużny, Nowy Sobór Ogólnoprawosławny, pg.

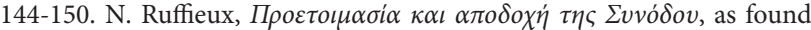

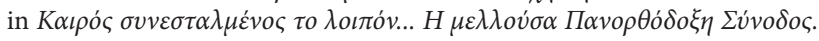

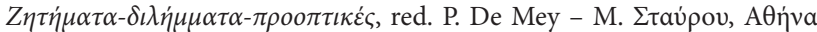

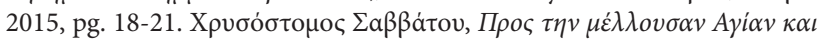

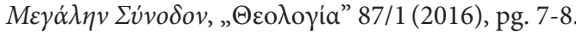

serve as a basis for discussion at the up-coming pro-Synodal Conference. The participants changed the list of 17 topics set out in 1930 by establishing a new list and expanding them to over 100 topics in 8 categories. Among the proposed topics, the following point was found in the fourth category: Autocephaly and Autonomy in the Orthodox Church a) the proclamation of autocephaly: who proclaims $i t$; is conditions and limitations; the manner of proclaiming autocephaly; Churches currently regarded as autocephalous. ${ }^{6}$ The conference in Rhodes was an expression of the deep awareness of pan-Orthodox unity and an announcement of the revival of the activity of the Orthodox Church's institution of conciliarity. The question of autocephaly was not addressed at the Second and Third Pan-Orthodox Conferences in Rhodes on September 26-30 and November 1-15, 1964, the Fourth Pan-Orthodox Conference in Chambésy on June 8-15, 1968 and the Frist Pre-Conciliar Pan-Orthodox Conference in Chambésy on July 16-28, 1971. ${ }^{7}$

The First Pre-Conciliar Pan-Orthodox Council took place in Chambésy on November 21-28, 1976. Three committees were called into being in order to consider particular points of the Conference. The first committee revived the list of topics and the manner of preparing the upcoming Council. We read in the committee's report that all representatives agreed that Autocephaly and Autonomy in the Orthodox Church among the topics should be found. In addition, six representatives suggested that the abovementioned that The Manner of Proclaiming Autocephaly, two representatives recommended that it clarified the question of proclaiming autocephaly, who proclaims it, the conditions and requirements be clarified, and one representative proposed explanation of which Churches are currently acknowledged as autocephalous. ${ }^{8}$ After a detailed analysis of the topics, ten of them were selected, among which was found autocephaly and the manner in which it is proclaimed. ${ }^{9}$

The Second Pre-Conciliar Pan-Orthodox Conference, which took place in Chambésy on September 3-12, 1982 did not deal with the topic of autocephaly, but rather postponed its discussion to the following Conference (October $28^{\text {th }}$ - November 6, 1986). ${ }^{10}$ This conference approved four documents while ignoring the question of autocephaly. During the conference, the chairman, Metropolitan Chrysostomos of Myra, referred to the remaining four topics

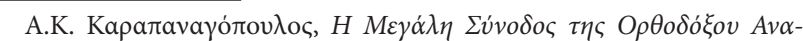

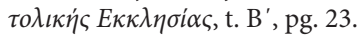

Ibidem, pg. 31, 64, 87-88. J. Klinger, Konferencja przedstawicieli Kościołów prawosławnych $w$ Chambésy koło Genewy, „Cerkiewny Wiestnik” 15 (1968), nr 8, pg. 12-14. T. Kałużny, Nowy Sobór Ogólnoprawosławny, pg. 161-177.

8 Ibidem, t. $\Gamma^{\prime}$, pg. $43,48-52$.

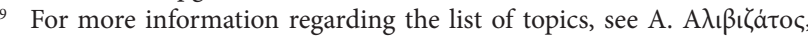

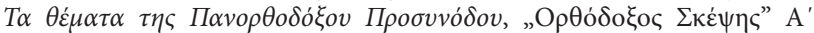

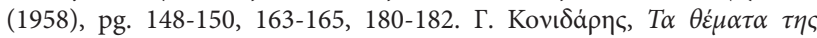

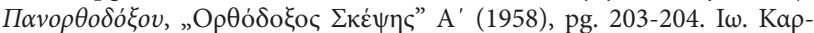

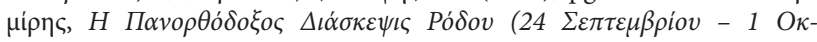
$\tau \omega \beta$ piov 1961), AӨńvaı 1961. J. Anchimiuk, Przygotowania do Soboru Wszechprawosławnego, „Studia i Dokumenty Ekumeniczne” 1 (1983), nr 1, pg. 70-71. T. Kałużny, Nowy Sobór Ogólnoprawosławny, pg. 177-186.

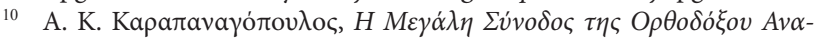

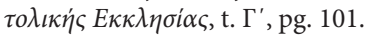


during his address: Orthodox diaspora; autocephaly and the manner of its proclamation; autonomy and the manner of its proclamation; and diptychs. It was decided to include them in the agenda of the Fourth Pre-Conciliar Pan-Orthodox Conference. Metropolitan Chrysostomos drew attention to the difficulty of the discussion caused by the mutual dependency of particular topics. Undoubtedly, the complicated issue of the diaspora cannot be considered independently from the principles that are essential in the case of granting autocephaly and autonomy. Even the seemingly simple topic of diptychs cannot be examined and considered without parallel explanation and sanctioning of existing rules in the Church regarding autocephaly and autonomy. He explained that the question of autocephaly and the manner of its proclamation is currently a method of joining the Orthodox Church into one body. He asked for the establishment of uniform principles and the rejection of pluralism when applying this system. ${ }^{11}$

The Fourth Pre-Conciliar Pan-Orthodox Conference was debated in November, 1993 in Chambésy under the leadership of Metropolitan Chrysostomos of Ephesus, Prior to discussion about the question of autocephaly, Metropolitan Damascenus of Switzerland gave an introductory speech $^{12}$ in which he introduced the contribution of particular Local Churches to the abovementioned topic on the basis of comments sent to the secretary's office. He stated that all of the Holy Churches agree:

- with the ecclesiastical grounds and application of the institution of autocephaly in the Orthodox Church;

- that only the ancient canonical tradition can create a mutually acknowledged foundation necessary for overcoming contemporary problems;

- with the explanation of ecclesiastical conditions required for granting autocephaly;

- with the fact that pan-Orthodox consensus is required to proclaim a particular local Church autocephalous, beginning with the sanctioned imitative of the Ecumenical Patriarch and then by the proposal of the Mother Church or jointly;

- with accenting the liturgical union of the institution of autocephaly and the ecclesiastical administration in general, regarding joint responsibility of all local Orthodox Churches in observing Church unity in the community of faith and union of love ${ }^{13}$;

- liturgical relations determine mutual care for avoiding unilateral or historically motivated explanations of the institution of autocephaly

- concerning the pan-Orthodox significance of the fact of integrating a particular local Church to the community of Autocephalous Orthodox Churches. The proposal

\footnotetext{
11 Ibidem, pg. 124-125. T. Kałużny, Nowy Sobór Ogólnoprawosławny, pg.

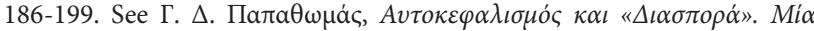

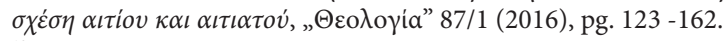

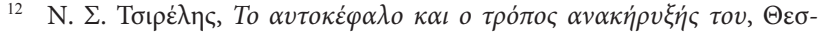

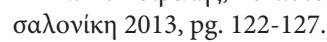

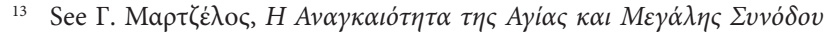

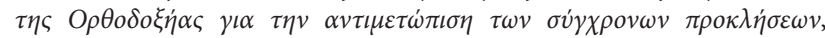

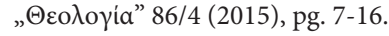

to subordinate the relations of a Church leaving its Mother Church, which would reserve the right for its potential liquidation was also put forward. The known rule of mutual perichoresis between the local and Ecumenical (Universal) Church in Orthodox tradition and practice was also mentioned.

After a long discussion, the Fourth Inter-Orthodox Preparatory Commission accepted the text of the document on autocephaly and the manner of its proclamation. It was accepted that the institution of autocephaly faithfully expresses the Orthodox ecclesiastical tradition in the question of the relations of the local Church with the universal Church of God. The Orthodox Church is uniform in terms of ecclesiology and canonicity. The perichoresis of the local and universal element specifies the liturgical relationship between the administrative organization and unity of the Church. Autocephaly therefore follows from care for the most effective application of ecclesiastical administration. The Mother Church accepts a request from of its dependent local Churches, which desires to become independent by obtaining autocephalous status. It evaluates all the ecclesiological, canonical and pastoral conditions that determine if the local Church is able to function as an independent organism. The Mother Church then submits a proposal to the Ecumenical Patriarch and informs the other Autocephalous Churches. The Ecumenical Patriarch seeks a pan-Orthodox consensus which is required to make a final decision about granting autocephaly before its proclamation. ${ }^{14}$

The consent of the Mother Church ${ }^{15}$ for submitting the request for autocephaly constitutes the rule of canonical law. The proclamation of autocephaly assumes the prior consent of the Church from whose jurisdiction is a specific ecclesiastical area is given. Autocephaly is granted to the local Church by the whole Orthodox Church. According to canonical law, the Ecumenical Council, a pan-Orthodox council or the consent of all Autocephalous Orthodox Churches serve as the competent organ for proclaiming autocephaly ${ }^{16}$ In the case that it is not possible to accept the document regarding autocephaly at a pan-Orthodox council, the only method of proclaiming autocephaly is a procedure applied historically and customarily. The co-ordinating role of the Ecumenical Patriarch reflects the formed canonical order and guarantees the unity of the Orthodox Church without neglect or diminishing the Autocephalous Churches' independence and right to self-governance. As a result, unilateral proclamation of autocephaly by the Mother Church and the subsequent formal consent of the other autocephalous Church manifests serious canonical prob-

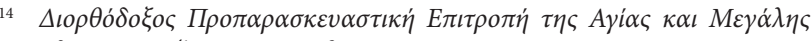

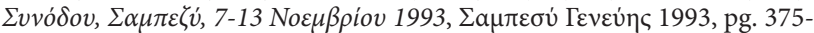
377 .

15 Ibidem, pg. 319.

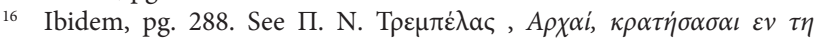

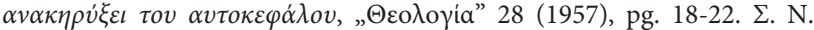

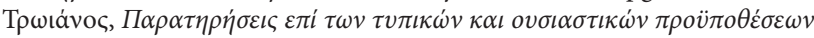

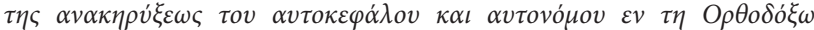

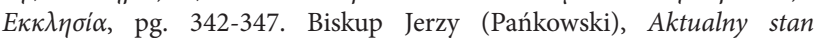
przygotowań do Soboru Panprawosławnego, „Elpis” 12 (2010), pg. 172-173.
} 
lems since if a Mother Church can independently grant a part of its jurisdiction autocephaly, we thereby rule out the need for the consensus of the whole Church.

The question of the lack of consensus results from the text of the document on autocephaly in paragraph $3 \mathrm{c}$ : "In expressing the consent of the Mother Church and the pan-Orthodox consensus, the Ecumenical Patriarchate officially proclaims the autocephaly of the applying Church by the publication of a patriarchal Tomos. The Tomos is signed by the Ecumenical Patriarch. It is desirable that is be cosigned by the primates of the Autocephalous Churches, but in any case, it must be signed by the primate of the Mother Church." ${ }^{17}$ The fragment of the paragraph cited above was submitted for discussion at the next Inter-Orthodox Preparatory Commission in December, 2009. The main objective of the meeting was to seek a solution to the question of "who signs the Tomos for proclaiming a local Church autocephalous." Two points of view have been developed based on the text. According to the first view, only the Ecumenical Patriarch, being the voice of pan-Orthodox consensus, signs the Tomos. The second point of view states that the Ecumenical Patriarch signs the Tomos proclaiming autocephaly along with the leaders of all local Orthodox Churches without any distinction, or at least the Ecumenical Patriarch and primate of the Mother Church. Supporters of the second approach refer to the rule of equality of all Churches regardless if they possess Apostolic succession or date back to antiquity. In their opinion, the Mother Church is responsible for the whole procedure and which is jointly responsible together with the remaining Autocephalous Orthodox Churches for preserving pan-Orthodox unity and canonical order. Moreover, the Mother Church from whose jurisdiction an area is given to a to become an independent Church, even if it can regulate issues of its autonomous administration, nevertheless cannot apply the rule of integrating a Church into the community of the remaining autocephalous Churches on its own. ${ }^{18}$

Autocephaly is an action which requires setting up new ecclesiastical powers for the new local Church. In accordance with canonical tradition and practice, a newly proclaimed Autocephalous Church takes an independent position in the system of autocephalous Orthodox Churches and from this point, independently shapes relations with remaining Autocephalous Churches. Simultaneously, it is excluded from any previous dependency on the Church from which it was separated. ${ }^{19}$ Granting autocephaly is a very significant issue as it cannot fall under the competences of a particular individual local Church, but of the entire Church. In addition, a Mother Church has the honour and unique privilege of granting permission for commencing the procedure of obtaining consensus from all autocephalous Orthodox Churches by the Ecumenical

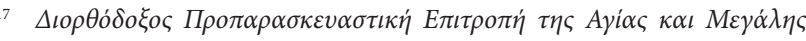

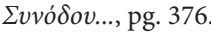

18 Biskup Jerzy (Pańkowski), Aktualny stan przygotowań do Soboru Panprawosławnego, pg. 173.

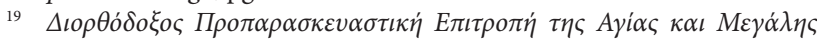

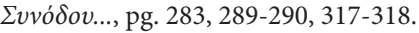

Patriarch. If we accept the view supporting the dominant role of the Mother Church or the parallel conditions for signing a Tomos proclaiming autocephaly by all Churches, the issue of respecting the honorary seniority of the Ecumenical Patriarch in relation to the remaining Autocephalous Churches then appears. The risk of disrupting the canonical tradition based on the role of honorary seniority in the question of the procedure of granting autocephaly by the Ecumenical Patriarch is also posed.

Advocates of the position that the Ecumenical Patriarch's signature is sufficient to proclaim autocephaly desire to preserve sanctioned canonical order. The canonical primacy of the Ecumenical Patriarch and the relations between the first and synod grant him the right, ${ }^{20}$ after obtaining prior consensus of the entire Church, to proclaim autocephaly exclusively by means of his signature. In this way, he confirms pan-Orthodox consensus that witnesses that granting autocephaly results from a decision made by the entire Church.

The Inter-Orthodox Preparatory Commission elaborated a joint decision with regards to signing a Tomos proclaiming autocephaly by the Ecumenical Patriarch as a representative of all the remaining hierarchs of the Orthodox Churches $\sigma v \mu \mu \alpha \rho \tau v \rho o v v \tau \omega v \quad \varepsilon v \alpha v \tau \omega^{21}{ }^{21}$ Further meetings dedicated to the text of the document on autocephaly, in particular the manner of signing the Tomos by the hierarchs of Churches, was postponed for final drafting at the next Inter-Orthodox Preparatory Commission in February, 2011. During the discussion, four propositions were set forth, in particular, that a Tomos proclaiming autocephaly be signed by the Ecumenical Patriarch with a handwritten note stating $\alpha \pi \circ \varphi \alpha i v \varepsilon \tau \alpha \iota$ (expressing consent) followed by a note made by the remaining hierarchs of the Autocephalous Churches $\sigma v v \alpha \pi \circ \varphi \alpha i v \varepsilon \sigma \theta \alpha$ ( (expressing joint consent). According to the second proposal, the Ecumenical Patriarch signs the Tomos as he did previously with the formula $\sigma v v \alpha \pi о \varphi \alpha i v \varepsilon \sigma \theta \alpha \iota$ next to the signatures of the Church's hierarchs or without any note at all. In the case of the third proposal, the Tomos is signed as stated above with a declaration in the text of the document about the equality of all the hierarchs. According to the fourth and final proposal, the Ecumenical Patriarch signs the Tomos with a handwritten phrase stating $\alpha \pi o \varphi \alpha i v \varepsilon \tau \alpha \iota \mu \varepsilon \tau \dot{\alpha} \pi \dot{\alpha} v \tau \omega \nu \tau \omega \nu$

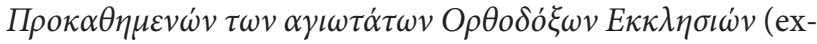
pressing consensus along with all the hierarchs of the Holy Orthodox Church). The proposals mentioned above were rejected by the Russian Orthodox Church, which held to their proposal of signing a Tomos proclaiming autocephaly by all the hierarchs according to the order of diptychs without any additional notes beside their signatures. Since none of the abovementioned proposals were accepted unanimously, the commission did not send the text about

\footnotetext{
$20 \quad$ Ibidem, pg. 316. J. P. Manoussakis, Primacy and Ecclesiology: The state of the Question, as found in Orthodox Construtions of the West, red. A. Papanikolaou, G. Demacopoulos, New York 2013, pg. 229-239.

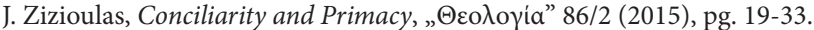

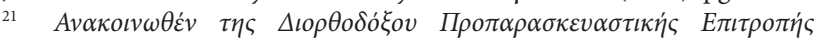

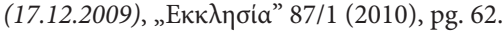


the Tomos proclaiming autocephaly for further discussion. As a result of this lack of consensus regarding the proclamation of autocephaly during the Pre-Council Conference, this topic was not placed on the agenda of the Great and Holy Synod. ${ }^{22}$

On the basis of the overview given above of the procedures concerning the question of autocephaly and the manner of its proclamation, we can conclude that creating a newly formed Autocephalous Church with the consensus of the Mother Church is an extremely difficult task. It seems to be outright unlikely that the Serbian Orthodox Church would agree to granting the Macedonian Orthodox Church autocephaly or that the Russian Orthodox Church would agree to creating an autocephalous Ukrainian Orthodox Church. We will experience similar barriers that are impossible to overcome and we will most likely have to deal with the question of the diaspora more often as the example of the American OCA indicates. ${ }^{23}$

The term $\sigma v v \alpha \pi \circ \varphi \alpha i v \varepsilon \tau \alpha \iota$ differentiates local Churches from the Ecumenical Patriarchate. According to the Bishop Cyril of Avidou, this does not constitute a problem, under the condition that there exists voluntary consent from each of the Churches for creating a new Autocephalous Church and when the Ecumenical Patriarch is treated, on the basis of the canons, as the first among the remaining local Churches..$^{24}$ Even more so that all of the Autocephalous Churches have received ecclesiastical independence from him and the majority of them were found in his jurisdiction. The decision and initiative of editing a Tomos proclaiming autocephaly belonged to the Ecumenical Patriarch, after which the procedure of obtaining consensus from all the Autocephalous Churches was commenced. After receiving the approval of all the local Churches, their hierarchs sign the prepared document, thus expressing their consent to the previously edited document. It is clear that since the consent for autocephaly was expressed by the first, then all of the remaining confirm their approval and thus confirm the content of the previously prepared Tomos.

The proposal of the Russian Orthodox Church with regards to signing the Tomos in accordance with the order of diptychs is not possible, because the local Churches have

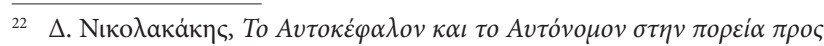

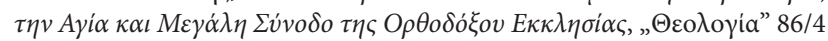
(2015), pg. 201-209.

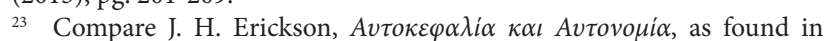

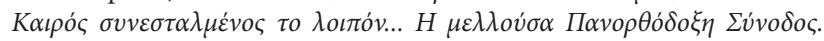
$Z \eta \tau \dot{\eta} \mu \alpha \tau \alpha-\delta \iota \lambda \dot{\eta} \mu \mu \alpha \tau \alpha-\pi \rho о 0 \pi \tau \iota \kappa \varepsilon \dot{\varepsilon}$, pg. 149-182.

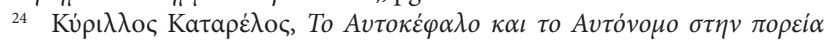

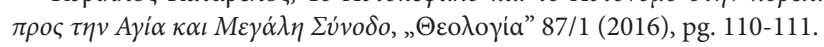

not received approval in the abovementioned matter, which has not been added to the agenda of the Great and Holy Council. Another fact still remains that if Tomoses which have proclaimed autocephaly over the last two centuries by the Ecumenical Patriarchate at times anticipate that the autocephaly granted or in a few cases, patriarchal dignity, should be accepted by an Ecumenical Council, there is no mention of this in the currently proposed texts.

The difficulty in working out a common view on autocephaly does not mean that not progress has been made by the local Churches. It should be stated that a unanimous point of view concerning the procedure of granting autocephalous status has been elaborated, in particular:

a) The representatives (clergy and laity) of a particular ecclesiastical area submit a request for granting autocephaly to the Mother Church.

b) The Mother Church's synod studies and evaluates the canonical and pastoral conditions for granting autocephaly. In the case that the request has been positively considered, the Mother Church submits a petition to the Ecumenical Patriarchate in order to ensure pan-Orthodox approval. At the same time, it informs the remaining local Orthodox Churches.

c) The Ecumenical Patriarch officially informs, by means of a patriarchal letter, of the abovementioned petition and the positive standpoint of the Mother Church and ask for unanimous consent confirmed by a synodal decision of individual local Churches.

d) After the Ecumenical Patriarch confirms that pan-Orthodox consensus has been reached, he issues a Patriarchal Tomos proclaiming autocephaly of a particular ecclesiastical area.

These four stages in the process of granting autocephalous status have been unanimously accepted by all local Churches. The manner of granting autocephalous status in the Orthodox Church is an extremely important question today and is awaiting a solution by establishing commonly accepted canons which guarantee the preservation of Orthodox unity. The difficulties experienced in the discussion are caused a the lack of specific and clear canonical resolutions regarding the meaning of autocephaly, the conditions of granting it, who is the responsible organ for its granting or deprivation, and also concerning the internal relations of daughter Churches with their Mother Churches and their relations with the remaining Autocephalous Churches. This lack of commonly elaborated canons has led to a situation in which canonists and historians attempt to create rules which will answer the increasing amount of questions by creating and implementing general rules. 


\section{Bibliografia}

\section{Źródła}

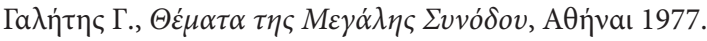

Kałużny T., Nowy Sobór Ogólnoprawosławny. Natura, historia przygotowań, tematyka, Kraków 2008.

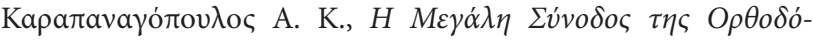

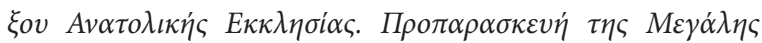

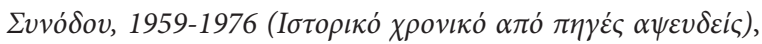

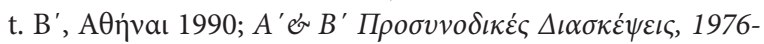

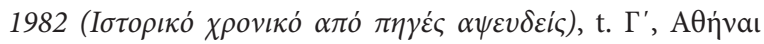

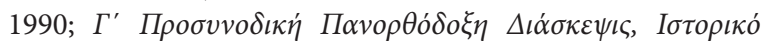

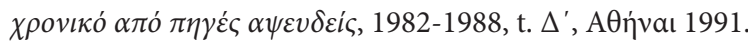

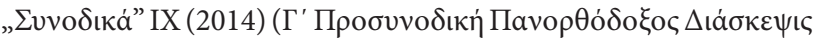

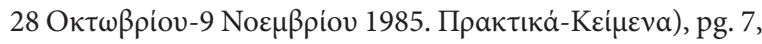
189-191, 198-199, 286-289, 326-327, 330.

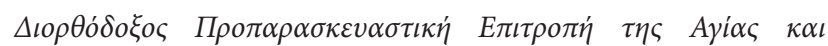

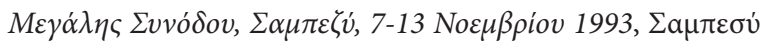
Гeveúnৎ 1993, pg. 283, 288-290, 317-319, 375-377.

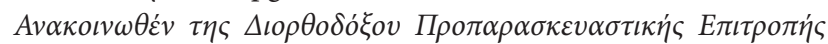

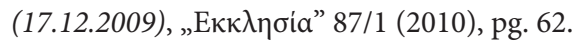

\section{Monografie, artykuły, opracowania}

Anchimiuk J., Przygotowania do Soboru Wszechprawosławnego, „Studia i Dokumenty Ekumeniczne” 1 (1983), nr 1, pg. 69-71.

Jerzy Bp (Pańkowski), Aktualny stan przygotowań do Soboru Panprawosławnego, „Elpis” 12 (2010), pg. 163-175.

Jerzy Bp (Pańkowski), Czym jest sobór (Sobór Wszechprawosławny) dla Kościoła? Perpektywa prawosławna, „Polski Żołnierz Prawosławny” rok XXIII, nr 2/88 (2016), pg. 3-7.

Klinger J., Konferencja przedstawicieli Kościołów prawosławnych w Chambésy koło Genewy, „Cerkiewny Wiestnik” 15 (1968), nr 8, s. 12-14.

Leśniewski K., Jedność chrześcijan w oficjalnych wypowiedziach Kościoła prawosławnego, „Sympozjum” 4 (2000), nr. 1, pg. 21-37.

Manoussakis J. P., Primacy and Ecclesiology: The state of the Question, as found in Orthodox Construtions of the West, red. A. Papanikolaou, G. Demacopoulos, New York 2013, pg. 229-239.

Meimaris T. A., The Holy and Great Council of the Orthodox

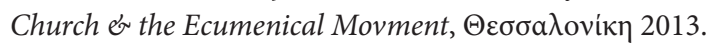

Tofiluk J., O przygotowaniach do Soboru Wszechprawosławnego, „Elpis” 1 (1999), nr 1, pg. 69-84.

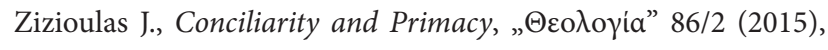
pg. 19-33.

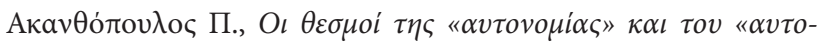

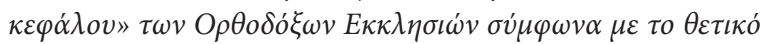

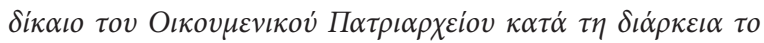

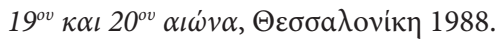

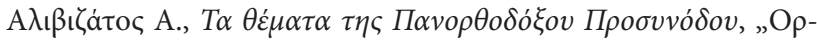

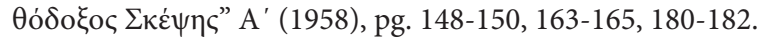

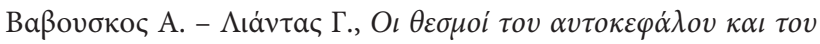

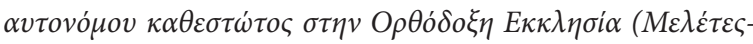
$\Pi \eta \gamma \varepsilon \dot{\varepsilon}), \Theta \varepsilon \sigma \sigma \alpha \lambda$ ovík 2014.

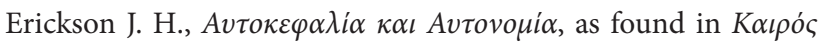

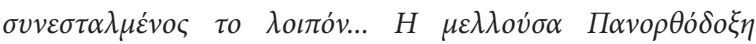

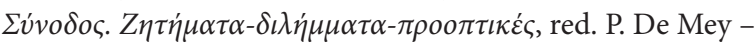

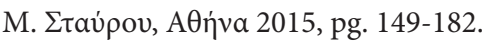

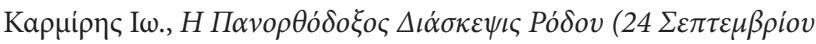

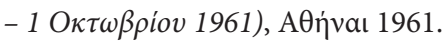

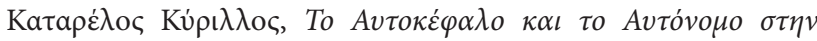

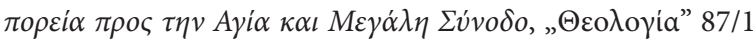
(2016) 107-122.

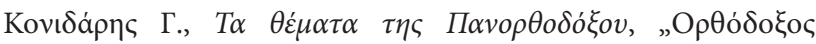

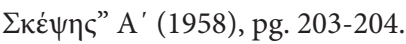

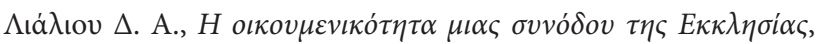

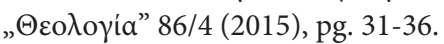

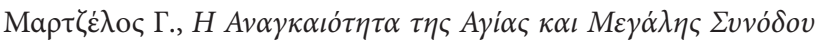

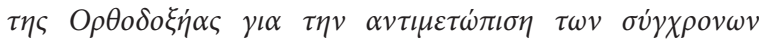
$\pi \rho о \kappa \lambda \eta \dot{\sigma \varepsilon \omega v, ~ „ \Theta \varepsilon o \lambda o \gamma i ́ a ” ~ 86 / 4 ~(2015) ~ 7-16 . ~}$

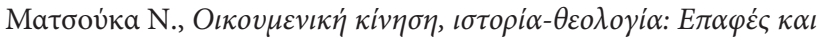

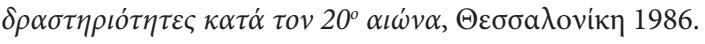

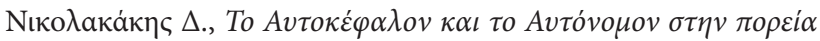

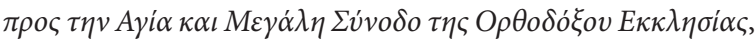

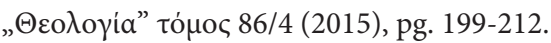

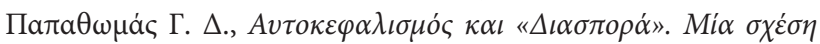

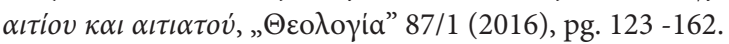

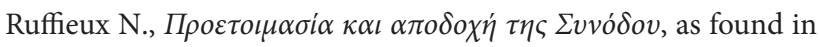

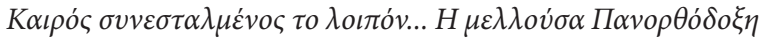

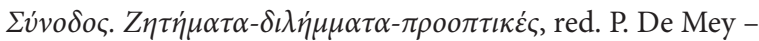

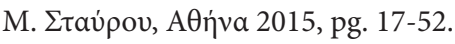

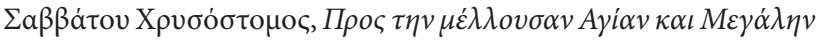

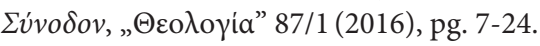

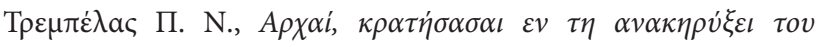

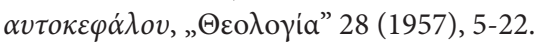

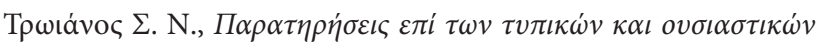

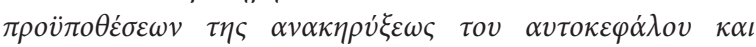

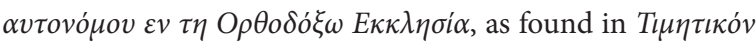

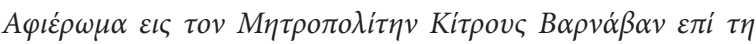

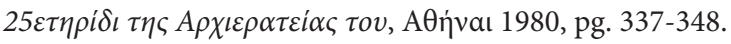

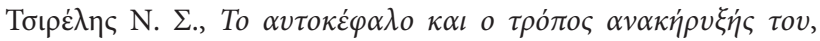
$\Theta \varepsilon \sigma \sigma \alpha \lambda$ ovíkך 2013.

$\Phi \varepsilon ı \delta a ́ \varsigma, ~ B \lambda ., ~ T o ~ « \alpha v \tau o \kappa \varepsilon ́ \varphi \alpha \lambda o v » ~ \kappa \alpha \iota ~ \tau o ~ « \alpha v \tau o ́ v o \mu o v » \varepsilon v i \eta$

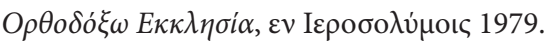

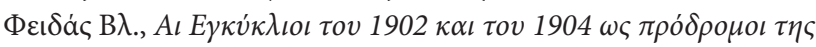

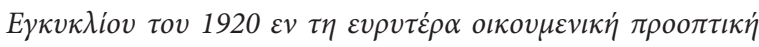

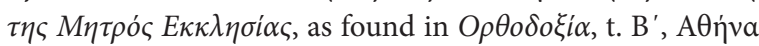
2003, pg. 129-139. 